\title{
Managing Roof Rats and Deer Mice in Nut and Fruit Orchards
}

NIAMH QUINN, University

of California Cooperative

Extension advisor, South Coast

Research and Extension Center, Irvine; and ROGER A. BALDWIN,

UCCE wildlife specialist,

UC Davis.

\section{Abstract}

Effective rodent management is critical for the control of damage from these agricultural pests to nut and fruit trees in California and the rest of the United States. As yet, no one has developed an effective management plan for roof rats (Rattus rattus) and deer mice (Peromyscus spp.) in California orchards. In this publication, we describe an effective management plan using $0.005 \%$ diphacinonetreated oats placed in elevated bait stations. In particular, we look at the specific types of damage that rodents cause in orchards-information you need to know in order to implement an effective baiting program - and we give a cost estimate for a baiting program. The elevated baiting program that we propose should provide effective and cost-effective control for roof rats and deer mice in nut and tree fruit orchards, while posing little risk to the natural environment.

Invasive, non-native vertebrate species cause an estimated $\$ 39$ billion in damage in the United States each year (Pimentel 2011). Rats (Rattus spp.) are extremely common invasive pests found throughout most of the United States in both urban and agricultural areas and are thought to be among the main causes of damage. In fact, one report puts the annual costs of damage caused by rats at $\$ 19$ billion (Pimentel, Zuniga, and Morrison 2005).
More specifically, rats and mice are known to cause considerable damage in nut and fruit trees in the United States (Kern 2012; Pearson, Gorenzel, and Salmon 2000; Tobin, Koehler, and Sugihara 1997). In nut crops, damage to developing macadamia nuts from invasive rats has been estimated to be between 5 and 10\% (Tobin, Koehler, and Sugihara 1997). Native rodent species can also cause a lot of damage, with estimates for damage from deer mice ( $P$. spp.) of $\$ 20.64$ per acre ( $\$ 51$ per hectare) in some almond orchards in Fresno County, California (Pearson, Gorenzel, and Salmon 2000).

Clearly, effective rodent control is critical for the prevention of damage to agricultural crops. Worldwide, rodenticide baits are the mostly commonly preferred means for rat and mouse control, given their low cost and high efficacy (Stenseth et al. 2003). In California, past and present control strategies have focused on flooding burrow systems (F. Rinder, Fresno County Agricultural Commissioner's office, pers. comm.), since few baiting options are available for these species. Flooding burrows, though, this is an inefficient use of time and resources. The development, efficacy verification, and registration of a baiting material and strategy for rat and deer mouse control in California orchards would be of great use. 
The efficacy and palatability of commercially available rodenticides can vary greatly, and bait effectiveness is often specific to particular pest species (Pitt, Driscoll, and Sugihara 2011). Many rodenticides have been developed to control rodent populations (e.g., brodifacoum, bromethalin, chlorophacinone, diphacinone, and zinc phosphide [Gill 1992; Pitt, Driscoll, and Sugihara 2011]), and several studies have assessed the materials' ability to control rats and mice in natural areas (Radvanyi 1980; Spurr et al. 2013). However, until now no peer-reviewed studies have tested the efficacy of rodenticides for roof rat control in nut or tree fruit crops, and few if any studies have been conducted on deer mice. We recently initiated an investigation into the efficacy of three rodenticide baits for control of roof rat and deer mouse activity in almond orchards and found that the $0.005 \%$ diphacinone oat bait, sold in many county Agricultural Commissioner's offices, was highly effective (Baldwin et al. 2014). This study made use of elevated bait stations, which proved effective at supplying bait to target species while substantially limiting access to rodenticides for many nontarget species.

The rodenticide formulation described here can be used against roof rats and deer mice in orchards.

In this publication we provide information on how to identify damage from roof rats and deer mice in nut and tree fruit orchards, and how to effectively implement a baiting program to control these pests. This appears to be an efficacious, cost-effective, and safe baiting protocol for control of roof rats and deer mice in orchard crops, something that has thus far been unavailable to growers.

\section{Identifying damage}

Accurate identification of the species responsible for damage is essential to the development of an effective pest management program. If your management plan focuses on the wrong species, it is likely to be ineffective and it may pose hazards to nontarget species and even be an illegal misuse of the material, based on the rodenticide label information. Fortunately, the presence of roof rats and deer mice can often be detected through indirect monitoring techniques. For example, roof rats often burrow at the bottom of trees, and these burrows are typically 2 to 3 inches in diameter (figure 1). Burrows of the California ground squirrel (Otospermophilus beecheyi) are sometimes this same size, but usually they are a bit larger (average diameter $=4$ inches). Also, if ground squirrels are present, you will see them running around above ground and hanging out in burrows.

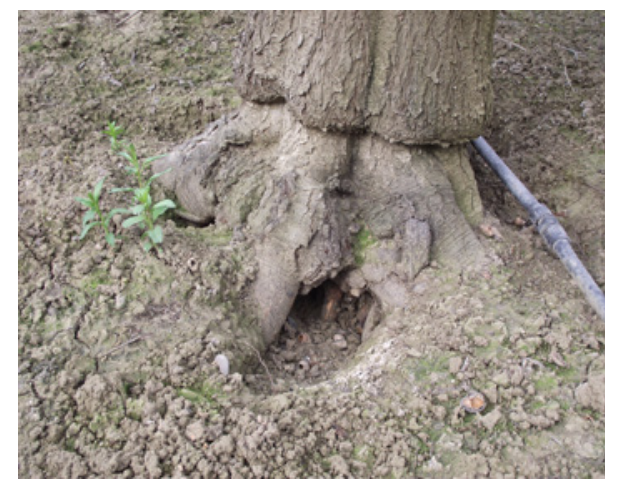

Figure 1. Example of a rat burrow at the bottom of an almond tree.

Discarded almond shells at the entrance of a burrow can help you determine the depredating species (figure 2), but distinguishing between damage from deer mice and roof rats can be difficult. Deer mouse burrow openings typically average around 1.5 inches in diameter. If burrow openings of this size are present, the depredating species may be the deer mouse. Vole (Microtus spp.) and deer mouse burrow openings are similar in size, but voles are not typically found in almond orchards, so long as ground cover is limited. If burrow openings are larger (2-3 inches), the roof rat is the likely culprit.

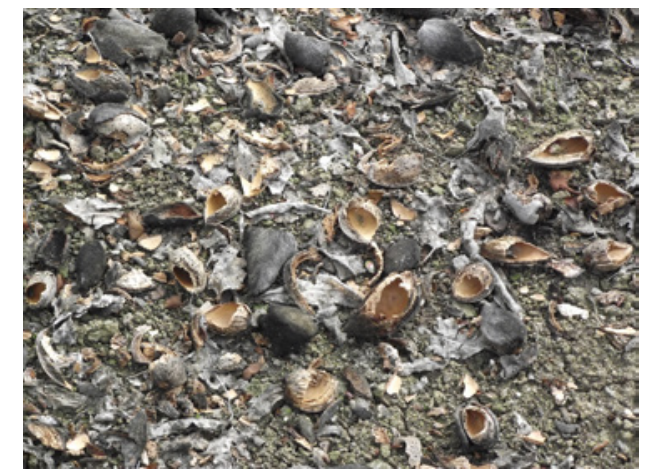

Figure 2. Example of almonds predated by rodents.

If you are still unsure about which species is responsible for damage in your orchard, you can place rat- and mouse-sized snap traps around areas where you have detected damage; this may in fact be the only way for you to discern between damage done by deer mice and by house mice (Mus musculus). Rather than snap traps, you can also use a remote-triggered game camera to determine the damaging species. Based on identification of the captured or photographed individual, you can then decide on an appropriate management plan. Further information on identifying roof rat and deer mouse species is available online at the UC IPM Pest Note website (www.ipm.ucdavis.edu/PMG/menu. vertebrate.html).

\section{Bait station design}

The bait stations used in our field trials were tubular structures manufactured specifically for Orange County Vector Control (Baldwin et al., 2014). The bait station consisted of high-density polyethylene plastic tubes that were 13 in $(33 \mathrm{~cm})$ long and 3.94 in $(10.8 \mathrm{~cm})$ inside 
diameter (figure 3). A steel end cap was fixed onto each end of the tube. Each end cap was penetrated with a 1.89 -in $(4.8-\mathrm{cm})$ opening, big enough to allow the roof rats and deer mice to enter the station and small enough to reduce or even eliminate any inadvertent loss of bait from the bait station. On the inside of the metal cap, under the opening, a 4.5-in long metal shelf is present. This also helps reduce bait loss. As of this writing, these bait stations are available for sale in a limited supply from the Los Angeles County Agricultural Commissioner's office. We are exploring additional supply options.

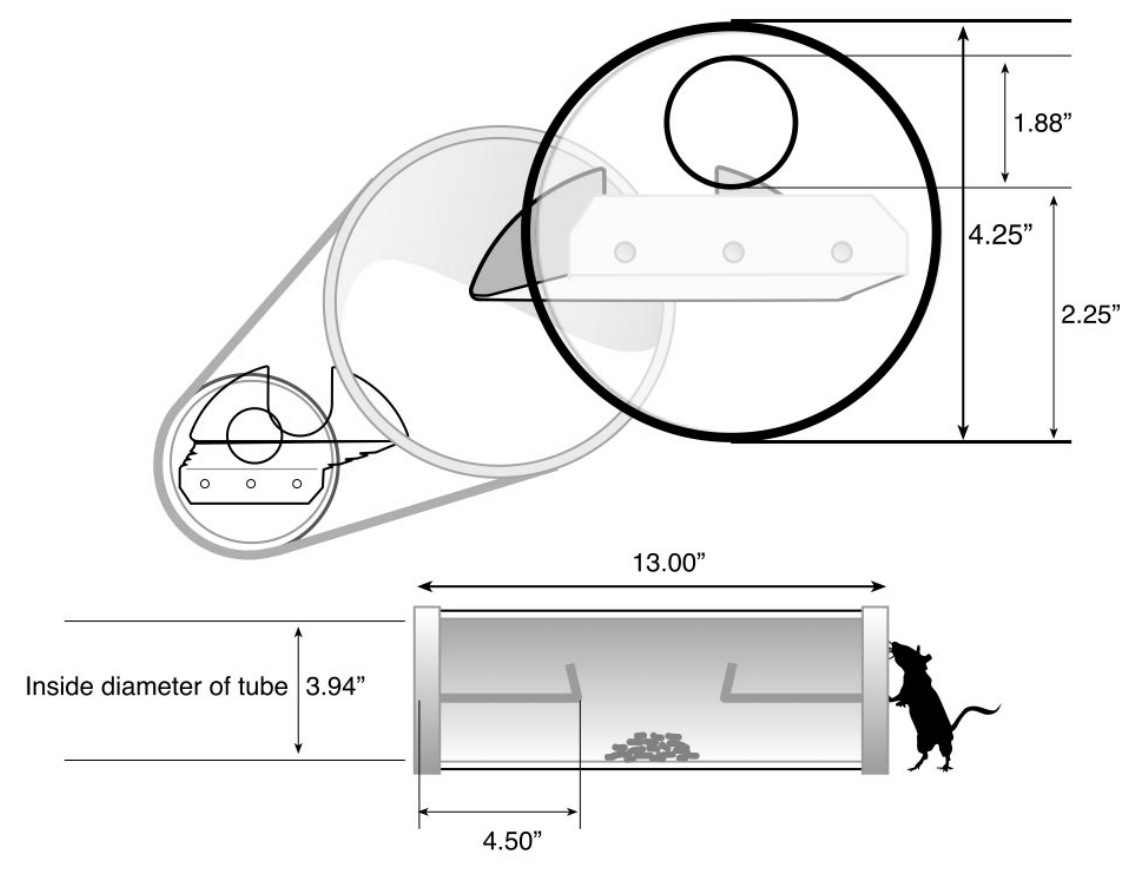

Figure 3. Design of bait stations used to control roof rats and deer mice.

\section{Bait application}

The current label for $0.005 \%$ diphacinone oat bait only allows baiting during the non-bearing season. This means that growers need to be proactive when dealing with rodent infestations. It is the responsibility of the grower to be aware of the presence of endangered species in orchards where they intend to implement a control program, since the bait may prove hazardous to nontarget species. The killing of an endangered species may result in a fine and imprisonment under the Endangered Species Act 1973.

The use of elevated bait stations will eliminate access to bait for many protected mammal species, such as kangaroo rats (Dipodomys spp.). Although other protected species, such as the Tulare grasshopper mouse

(Onychomys torridus tularen$s i s)$, are not usually associated with climbing trees, growers must be vigilant in areas where these and other protected species are found. Growers can consult the California Department of Pesticide Regulations PRESCRIBE website (www. cdpr.ca.gov/docs/endspec/prescint.htm) for any endangered species restrictions associated with bait application.

We recommend placing bait stations either 98 feet $(30$ $\mathrm{m})$ or 164 feet $(50 \mathrm{~m})$ from each other, throughout the orchard. Deer mice typically have a small home range (0.25 ac [0.1 ha] to 4 ac [1.6 ha]) (Timm and Howard 1994), so if the target species for your control program is the deer mouse only, you should use a 98 -foot spacing. This ensures that any deer mouse will have access to at least one bait station within its home range. Roof rats have a larger home range (e.g., 1.1-1.9 ac [0.45-0.78 ha]) (Whisson, Quinn, and Collins 2007), so the 164-foot spacing will put at least one bait station in each rat's home range while reducing the total number of bait stations required to effectively treat the orchard. If both roof rats and deer mice are present, use the 98 -foot spacing.

The number of bait stations needed across the length (NLength.aa, where ".aa" indicates the two decimal places allowed in the calculation result) and width (NWidth.bb, where ".bb" likewise indicates two decimal places) of each orchard can be determined using the following formulas:

$\frac{\text { Length of orchard }}{\text { Spacing }}=$ NLength.aa
$\frac{\text { Width of orchard }}{\text { Spacing }}=$ NWidth.bb

Since NLength. $a a$ and NWidth.bb are not likely to be whole numbers, growers should round them down to whole numbers before multiplying to determine the total number of bait stations (NBS) needed for the entire orchard (note that in a square orchard, NLength $=$ NWidth).

\section{NBS $=$ NLength $\times$ NWidth}

Bait stations should be evenly spaced in the orchard (figure 4). To determine the optimal placement of bait stations, you need to calculate how far from the edge of the orchard to place the initial bait stations (we will call this the distance from edge, or $D E$ ). For square orchards, this is calculated by multiplying.$a a$ by the spacing used in that orchard (either 164 or $98 \mathrm{ft}$ ). The 
resulting number should be divided by 2 to allow for spacing on both edges of the orchard (whether the two edges of length or the two edges of width).

$$
D E=\frac{. a a \times \text { spacing }}{2}
$$

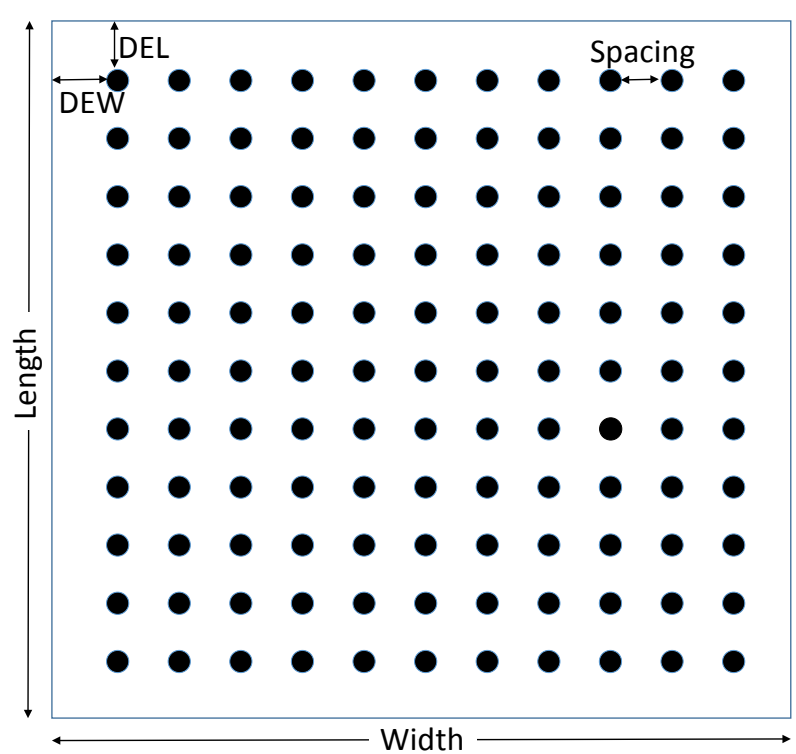

Figure 4. Example of the layout of bait stations (black-filled circles) for an 80-acre, square-shaped orchard. The length and width of the orchard are both $1,867 \mathrm{ft}$. In this example, only roof rats are present, so we use $164-\mathrm{ft}$ spacing between bait stations. Initial bait stations are $31 \mathrm{ft}$ from the edge of all sides of the orchard (DEL and DEW)

If the orchard is not square, you will need to calculate the distance from the edge for the orchard's length separately from the distance from the edge for its width. To do this, multiply .aa by the spacing used and then divide the result by 2 to give the distance from edge lengthwise (DEL), and multiply . bb by the spacing used and divide that result by 2 to give the distance from edge, widthwise $(D E W)$ :

$$
\begin{aligned}
& D E L=\frac{. a a \times \text { spacing }}{2} \\
& D E W=\frac{. b b \times \text { spacing }}{2}
\end{aligned}
$$

Here is an example of the calculations for a square, 80 -acre orchard $(1,867 \mathrm{ft} \times 1,867 \mathrm{ft})$ :

$$
\begin{aligned}
& \frac{\text { Length of orchard }}{\text { Spacing }}=\text { NLength.aa } \frac{1,867 \mathrm{ft}}{164}=11.38 \mathrm{ft} \\
& \frac{\text { Width of orchard }}{\text { Spacing }}=\text { NWidth.bb } \frac{1,867 \mathrm{ft}}{164}=11.38 \mathrm{ft}
\end{aligned}
$$$$
\text { NLength } \times \text { NWidth }=\text { NBS } 11 \times 11=121 \text { bait stations }
$$$$
\frac{. a a \times \text { spacing }}{2}=D E \quad \frac{0.38 \times 164 \mathrm{ft}}{2}=31 \mathrm{ft}
$$

These formulas will calculate the number of bait stations required for the orchard and also provide an approximate location for each bait station. Note, however, that the actual spacing between individual trees and rows of trees will dictate the ultimate placement of each bait station, which will in some cases be in the tree that is closest to the calculated location. Use bungee cords (figure 5) or wire to attach to bait stations to tree branches. Bungee cord takes less time than wire; wire is cheaper, but it is also harder to use and must be frequently replaced. Nylon cable ties were not effective for keeping bait stations securely attached to branches. To prevent spillage, bait stations should only be attached to branches that are at an angle of $45^{\circ}$ or less from the main trunk. Bait stations can be attached to the top or the underside of the branch, but must be rotated so the hole in each end cap is at the top (12 oclock position).

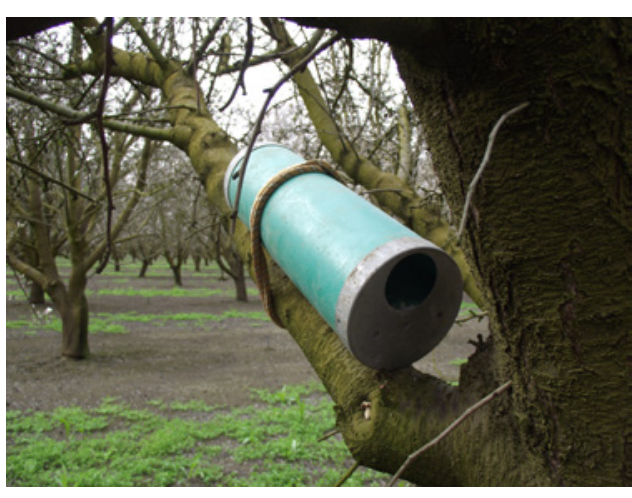

Figure 5. Bait station attached to the branch of an almond tree using a bungee cord.

An initial amount of one cup (approximately $0.25 \mathrm{lb}[113 \mathrm{~g}]$ ) of bait should be added to each bait station. Check the bait stations on a regular basis (for instance, every three days) to ensure a constant supply of bait; you can adjust the amount of bait you put in each station according to uptake. If necessary, you can put as much as 1 pound ( $454 \mathrm{~g}$ ) of bait per station at one time. It is important to note that diphacinone is a first-generation anticoagulant that requires multiple feedings to give the target species a toxic dose. As such, it is essential that you maintain a constant supply of bait in the stations throughout the duration of the baiting process.

You can deploy bait stations without bait for a few days at first to allow rodents to become acclimatized. After this initial period, keep replenishing the bait for around 4 weeks or until consumption stops. After cessation of a baiting program, you can keep the bait stations in place, but filled with non-toxic oats, in order to assess re-invasion by nearby roof rats or deer mice. If you do see evidence of re-invasion, you can continue baiting until the start of the growing season. 
Bait stations may also be deployed at ground level, but previous studies have found that elevated baits are more effective against roof rats than bait placed at ground level (Campbell, Koehler, and Sugihara 1998). Additionally, bait stations placed at ground level increase the likelihood that non-target animals (e.g., kangaroo rats) will fall prey to the bait.

Re-invasion rates can be high for many rodent species, with immigration occurring as soon as two months after control if adjacent areas are home to large populations (Spurr et al. 2013). As such, it is important to consider rat and mouse outbreaks and invasions at a broader, landscape level. Coordinated control programs implemented by neighboring landowners should provide the best results against damaging rat and mouse populations.

\section{Cautions when using bait stations}

In wet and humid conditions, the bait can absorb moisture. If this occurs, replace it with fresh, dry bait to maintain efficacy. Bait stations were designed to minimize spillage of bait during rodent feeding, but you still need to monitor for bait spillage and immediately clean up any spilled bait.

Deer mice have been known to nest in bait stations. Deer mice are known reservoirs of the Sin Nombre virus, which causes the potentially fatal Hantavirus Pulmonary Syndrome (Childs et al. 1994; Nichol et al. 1993). This virus is transmitted through the inhalation or ingestion of aerosolized saliva, feces, or urine of deer mice. Because of this, it is important to make sure that any wind is behind the bait application technician when he or she opens the bait stations, so that any aerosolized particles will be carried away, downwind.
Although concerns of secondary toxicity are typically quite low with first-generation anticoagulants (Baldwin and Salmon 2011; Lima and Salmon 2010; McMillin et al. 2008; Silberhorn, Schnabel, and Salmon 2006), they still hold some inherent risk. As such, the survey of pest carcasses is always an important part of implementing a baiting program using anticoagulants. During a baiting program, most rodents die below ground but a few will be found above ground. Check for aboveground pest carcasses once or twice a day. Remove the dead rodents and dispose of them by burying or burning (if permitted). Alternatively, you can wrap carcasses in newspaper or double-bag them and dispose of them in the trash. Latex or nitrile gloves should be worn when handling dead rodents to prevent potential infection from the various diseases or parasites they may carry.

\section{Cost analysis}

Initial start-up costs for an effective baiting program will vary depending on which pest species are present, since deer mice require more bait stations per acre than roof rats alone. At the time of this writing, the individual bait stations cost $\$ 4.72$ each, and 1 pound of the $0.005 \%$ diphacinone oat bait cost $\$ 1.75$. Estimated start-up costs, then, using the 164-foot spacing, would be approximately $\$ 624.07$ per 80 -acre orchard (table 1). Initial costs for deer mouse management would cost considerably more: $\$ 1,794.17$ per 80 -acre orchard (table 1). These estimates are based on initial placement of one cup of bait (approximately $0.25 \mathrm{lb}$ ) per bait station. If rates of infestation are high, you may need to place additional bait. Also, these estimates do not include tie-up or labor costs, which will vary considerably depending on the tying method you use (bungee cords or wire) to fasten bait stations to tree branches.
It is important to note that subsequent costs for bait programs go down dramatically, since the initial cost of bait stations accounts for the bulk of the expense of a start-up baiting program. The bait stations described are very durable and can be used across multiple fields and multiple years, further reducing the long-term cost of baiting programs. Ultimately, we believe this baiting strategy will allow for effective, economical management of roof rats and deer mice in nut and tree fruit orchards in most areas where these species are found. This approach also substantially reduces the potential for negative impacts from rodenticide bait on nontarget species, thereby minimizing the hazard to the natural environment.

\section{TABLE 1.}

Approximate initial start-up costs for a roof rat and/or deer mouse control program on an 80-acre orchard (Estimates do not include labor costs for placing and filling bait stations.)

\begin{tabular}{|c|c|c|c|c|}
\hline \multirow{2}{*}{ Expense } & \multicolumn{2}{|c|}{ 164-foot spacing } & \multicolumn{2}{|c|}{ 98-foot spacing ${ }^{*}$} \\
\hline & Quantity & Cost & Quantity & Cost \\
\hline $\begin{array}{l}\text { Bait stations } \\
\text { (for } 80 \text { acres) }\end{array}$ & 121 & $\$ 571.12^{\dagger}$ & 361 & $\$ 1,703.92^{\dagger}$ \\
\hline $\begin{array}{l}\text { Bait } \\
\text { (for } 80 \text { acres) }\end{array}$ & $30.25 \mathrm{lb}$ & $\$ 52.94^{\ddagger}$ & $90.25 \mathrm{lb}$ & $\$ 157.12^{\ddagger}$ \\
\hline TOTAL & & $\$ 624.06^{\S}$ & & $\$ 1,861.86^{\S}$ \\
\hline
\end{tabular}

We recommend 164-foot spacing between bait stations when only roof rats are present in the orchard. If both roof rats and deer mice are present in the orchard or only deer mice are present in the orchard, we recommend a 98 -foot spacing.

${ }^{\dagger}$ Estimates were based on a cost of $\$ 4.72$ per bait station.

Estimates were based on a cost of $\$ 1.75$ per pound.

${ }^{\diamond}$ Miscellaneous cost may vary depending on the attaching method. The cost of bungee cords was approximately $\$ 0.30$ each, while the cost of wire was approximately $\$ 0.02$ per bait station. 


\section{References}

Baldwin, R. A., N. Quinn, D. H. Davis, and R. M. Engeman. 2014. Effectiveness of rodenticides for managing invasive roof rats and native deer mice in orchards. Environmental Science and Pollution Research. 21:5795-5802

Baldwin, R. A., and T. P. Salmon. 2011. The facts about rodenticides. The Wildlife Professional 5:50-53.

Campbell III, E. W., A. E. Koehler, and R. T. Sugihara. 1998. The development of an integrated pest management plan for roof rats in Hawaiian macadamia orchards. Proceedings of the Vertebrate Pest Conference 18:171-175.

Childs, J. E., T. G. Ksiazek, C. F. Spiropoulou, J. W. Krebs, et al. 1994. Serologic and genetic identification of Peromyscus maniculatus as the primary rodent reservoir for a new hantavirus in the southwestern United States. Journal of Infectious Diseases 169:1271-1280.

Gill, J. E. 1992. A review of the results from laboratory tests of some rodenticides against eight rodent species. Proceedings of the Vertebrate Pest Conference 15:182-191.

Kern, Jr., W. H. 2012. Control of roof rats in fruit trees. University of Florida IFAS Extension Pub. SSWEC120. 5 pp.

Lima, L. L., and T. P. Salmon. 2010. Assessing some potential environmental impacts from agricultural anticoagulant uses. Proceedings of the Vertebrate Pest Conference 24:199-203.

McMillin, S. C., R. C. Hosea, B. F. Finlayson, B. L. Cypher, et al. 2008. Anticoagulant rodenticide exposure in an urban population of the San Joaquin kit fox. Proceedings of the Vertebrate Pest Conference 23:163-165.

Nichol, S. T., C. F. Spiropoulou, S. Morzunov, P. E. Rollin, et al. 1993. Genetic identification of a hantavirus associated with an outbreak of acute respiratory illness. Science 262:914-917.

Pearson, A. B., W. P. Gorenzel, and T. P. Salmon. 2000. Lesser-known vertebrate pests of almonds in California. Proceedings of the Vertebrate Pest Conference 19:365-376.
Pimentel, D. 2011. Biological invasions: Economic and environmental costs of alien plant, animal, and microbe species, Second Edition. CRC Press, Boca Raton, FL.

Pimentel, D., R. Zuniga, and D. Morrison. 2005. Update on the environmental and economic costs associated with alien-invasive species in the United States. Ecological Economics 52:273-288

Pitt, W. C., L. C. Driscoll, and R. T. Sugihara. 2011. Efficacy of rodenticide baits for the control of three invasive rodent species in Hawaii. Archives of Environmental Contamination and Toxicology 60:533-542.

Radvanyi, A. 1980. Control of small mammal damage in the Alberta oil sands reclamation and afforestation program. Forest Science 26:687-702.

Silberhorn, E. M., D. L. Schnabel, and T. P. Salmon. 2006. Ecological risk assessment for use of agricultural rodenticides in California. Proceedings of the Vertebrate Pest Conference 22:458-462.

Spurr, E. B., D. Foote, G. D. Lindsey, and C. F. Perry. 2013. Efficacy of hand-broadcast applications of diphacinone bait for rodent control in Hawaiian Montane Forests. Hawai'i Cooperative Studies Unit, University of Hawai'i at Hilo.

Stenseth, N. C., H. Leirs, A. Skonhoft, S. A. Davis, et al. 2003. Mice, rats, and people: The bio-economics of agricultural rodent pests. Frontiers in Ecology and the Environment 1:367-375.

Timm, R. M., and W. E. Howard. 1994. White-footed and deer mice. In Prevention and Control of Wildlife Damage. University of Nebraska Cooperative Extension, U.S. Department of Agriculture, and Great Plains Agricultural Council: Lincoln, NE.

Tobin, M. E., A. E. Koehler, and R. T. Sugihara. 1997. Effects of simulated rat damage on yields of macadamia trees. Crop Protection 16:203-208.

Whisson, D. A., J. H. Quinn, and K. C. Collins. 2007. Home range and movements of roof rats (Rattus rattus) in an old-growth riparian forest, California. Journal of Mammalogy 88:589-594. 


\section{Measurement Conversion Table}

\begin{tabular}{|l|c|c|l|}
\hline \multicolumn{1}{|c|}{ U.S. Customary } & $\begin{array}{c}\text { Conversion factor } \\
\text { for U.S. Customary } \\
\text { to Metric }\end{array}$ & $\begin{array}{c}\text { Conversion factor } \\
\text { for Metric to } \\
\text { U.S. Customary }\end{array}$ & \multicolumn{1}{c|}{ Metric } \\
\hline \multicolumn{5}{|c|}{ Length } \\
\hline foot $(\mathrm{ft})$ & 0.3048 & 3.28 & meter $(\mathrm{m})$ \\
\hline \multicolumn{5}{|c|}{ Area } \\
\hline acre $(\mathrm{ac})$ & 0.4047 & 2.47 & hectare $(\mathrm{ha})$ \\
\hline \multicolumn{5}{|c|}{ Mass } \\
\hline pound $(\mathrm{lb})$ & 0.454 & 2.205 & kilogram $(\mathrm{kg})$ \\
\hline pound per acre $(\mathrm{lb} / \mathrm{ac})$ & 1.12 & 0.89 & kilogram per hectare $(\mathrm{kg} / \mathrm{ha})$ \\
\hline
\end{tabular}

\section{For More Information}

To order or obtain ANR publications and other products, visit the ANR Communication Services online catalog at http:// anrcatalog.ucanr.edu or phone 1-800-994-8849. You can also place orders by mail or FAX, or request a printed catalog of our products from

University of California

Agriculture and Natural Resources

Communication Services

1301 S. 46th Street

Building 478 - MC 3580

Richmond, CA 94804-4600

Telephone 1-800-994-8849

510-665-2195

FAX 510-665-3427

E-mail: anrcatalog@ucanr.edu

(C) 2014 The Regents of the University of California

Division of Agriculture and Natural Resources

All rights reserved.

No part of this publication may be reproduced, stored in a retrieval system, or transmitted, in any form or by any means, electronic, mechanical, photocopying, recording, or otherwise, without the written permission of the publisher and the authors.

\section{Publication 8513}

ISBN-13: 978-1-60107-891-9

Revised March 2018

The University of California Division of Agriculture \& Natural Resources (ANR) prohibits discrimination against or harassment of any person participating in any of ANR's programs or activities on the basis of race, color, national origin, religion, sex, gender identity, pregnancy (which includes pregnancy, childbirth, and medical conditions related to pregnancy or childbirth), physical or mental disability, medical condition (cancer-related or genetic characteristics), genetic information (including family medical history), ancestry, marital status, age, sexual orientation, citizenship, or service in the uniformed services (as defined by the Uniformed Services Employment and Reemployment Rights Act of 1994: service in the uniformed services includes membership, application for membership, performance of service, application for service, or obligation for service in the uniformed services) or any person in any of its programs or activities.

University policy also prohibits retaliation against any employee or person participating in any of ANR's programs or activities for bringing a complaint of discrimination or harassment pursuant to this policy. This policy is intended to be consistent with the provisions of applicable State and Federal laws.
Inquiries regarding the University's equal employment opportunity policies may be directed to Linda Marie Manton, Affirmative Action Contact, University of California, Davis, Agriculture and Natural Resources, One Shields Avenue, Davis, CA 95616, (530) 752-0495. For information about ordering this publication, telephone 1-800-994-8849. For assistance in downloading this publication, telephone 530-750-1225.

To simplify information, trade names of products have been used. No endorsement of named or illustrated products is intended, nor is criticism implied of similar products that are not mentioned or illustrated.

An electronic copy of this publication can be found at the ANR Communication Services catalog website, http://anrcatalog. ucanr.edu.

\section{YEER}

REVIEWED This publication has been anonymously peer reviewed for technical accuracy by University of California scientists and other qualified professionals. This review process was managed by the ANR Associate Editor for Agricultural Pest Management, David Haviland.

12/14, 3/18-WJC,SB/RW/CR 